Artem Kosheliev, Graduate Student of the Department of Modern and Contemporary History of Foreign Countries, Faculty of History, Kyiv National Taras Shevchenko University

\title{
TRANSFORMATION OF THE THEORY AND METHODOLOGY OF BIOGRAPHICAL STUDIES IN THE AMERICAN AND WESTERN EUROPIAN ACADEMIC ENVIRONMENT DURING 1980-2016
}

\begin{abstract}
In the article based on modern studies of biography development by Western European and American scholars are demonstrated the changes in the approaches to writing biographies during the 1980-2016. Considering the processes of transformation of these studies in the context of changes in the intellectual climate of the Western European and American academic environment, the author demonstrates the ways in which the biography occupied an important place among academic studies. Also the article focuses on the connection between the "biographical turn" and the crisis of the historical narrative, caused by the proliferation of the postmodern narrative theory of historical discourse.

The need for the rethinking of approaches to the studies of individuals lives, especially prominent political and public figures, was due to the poor awareness of professional historians about their private life and the lack of clear tools for its study. In this regard, the rethinking of the theoretical foundations of biographical works is actualized and the search for new forms of writing biographies has become more active. This study demonstrates examples of new tools used by modern researchers in an attempt to move away from writing biographies in accordance of the patterns of the beginning of the 20th century as well as the reasons for such changes. One of the most important changes in this context was the application of new literary techniques in writing biographies, as well as the use of interviews and methods of oral history for their creation.
\end{abstract}

Key words: "biographical turn", biographical studies, theory and methodology, crisis of historical narrative

УДК 94(73):17.035.3«20»

http://doi.org/10.17721/2521-1706.2018.04.175-187

Тетяна Орлова, доктор історичних наук, професор, Київський національний університет імені Тараса Шевченка

\section{ФАКТОР АМЕРИКАНСЬКОГО НАЦІОНАЛЬНОГО ХАРАКТЕРУ У ПЕРЕМОЗІ ДОНАЛЬДА ТРАМПА}

\begin{abstract}
Анотація. У статті досліджуються впливи американського національного характеру на перебіг президентської кампанії 2016 року, здійснюється поєднання аналізу макро- $i$ макрорівнів, тобто електорального й індивідуального. Дональд Трамп продемонстрував свою близькість до більшості вибориів, апелював до американського характеру, спирався на певні його риси. Водночас начіональний характер виявився у його діяльності. Як свідчить історія, у кризових ситуаціях ті чи інші риси національного характеру можуть виходити на передній план, детермінуючи політичну поведінку людей. На теперішній момент Сполучені Штати Америки не уникли кризових явищ, що виявилося як в економіці, так і в ідентичності. Д.Трамп та його команда добре че відчули $i$ використали у своїи передвиборчій роботі. Натомість їхні суперники недооиінили значення психологічної складової в реальному історичному прочесі. Коментарі американських аналітиків із названої теми свідчать про відмінність поглядів «еліти» $i$
\end{abstract}


«маси». Перемога у виборах на найвищу посаду у провідній державі світу зайвий раз демонструє значення народних мас як твориів історії, а також факторів, які забезпечують успіх непересічним громадянам, до яких, безумовно можна віднести особу Д.Трампа.

Ключові слова: Сполучені Штати Америки, президентські вибори, національний характер, Дональд Трамп.

Сучасний світ безперервно одержує від Сполучених Штатів Америки найскладніше поєднання різноманітних імпульсів. Фактори, які їх визначають, також дуже різноманітні. Зокрема вони зумовлюються тими шляхами, якими рухається сама країна після чергових президентських виборів. 8 листопада 2016 р. 45-м президентом США було обрано Дональда Трампа. Обставини його перемоги піддані прискіпливому аналізу науковцями і політичними оглядачами різних країн $[1,2,3,4,5,6]$, у тому числі України $[7,8,9,10,11]$. В їхніх розвідках превалюють політичні, економічні, соціальні, демографічні, етнічні чинники, та мало уваги приділяється феномену національного характеру. Однак без врахування цього фактору не можна зрозуміти жодну драматичну подію у сучасній політичній історії світу, а перемогу екстраординарного для американського політикуму кандидата на президентських виборах провідної держави інакше не назвати.

У Сполучених Штатах Америки аналітики представили свої міркування 3 цього приводу. Серед них: Дж.А.Бартка [12], Р.Гонсалес [13], К.І.Кінг [14], Д.П.Макадамс [15], М. Марделл [16], М.Меєропол [17], Й.Міачем [18], Дж.Флаттум [19], М.Флемінг [20], Х.Харе [21], Ст.Хендерсон [22], Й.Хуер [23] та ін. У студіях названих авторів за звичай акцентується той чи інших аспект проблеми, або проблема розглядається у взаємозв'язку з іншими міркуваннями щодо перемоги Дональда Трампа. У вітчизняній історіографії із зазначеної теми поки що відсутні відповідні публікації. Мета пропонованої до уваги статті полягає у всебічному визначенні впливу феномену національного характеру на перебіг політичного життя сучасної Америки, що мав конкретне виявлення у передвиборчих перегонах 2016 року та їх результатах. Опертя на оприлюдненні роздуми американських фахівців буде доповнене і розвинуто.

Актуальність теми, з одного боку, визначається політичними міркуваннями: врахування впливу фактору національного характеру на політичну сферу не тільки США, а й України. 3 іншого боку, важливо мати на увазі: на нинішньому етапі історична наука зіткнулася із комплексом проблем, які вимагають нових концептуальних підходів до пояснення процесів і подій минулого і сьогодення. Суто позитивістські підходи є недостатніми для пояснення і прогнозування можливо, нових, але необхідних завдань істориків, яким конче необхідно об’єднувати свої зусилля із представниками інших соціогуманітарних наук, зокрема із соціологами, психологами, етнографами, політологами (у деяких публікаціях, присвячених дослідженню національного характеру як такого, вказуються також психологічна антропологія, історична етнологія, етнопсихологія, філософія тощо [24, с. 45]). Необхідність розширення наукових обріїв фахових істориків добре усвідомлюється у сучасних університетах США, де при підготовці спеціалістів зберігається настанова, що йде від засновників американської антропології Ф.Боаса і А.Кребера: вчений мусить володіти основами суміжних соціогуманітарних наук і бачити їхній взаємозв'язок.

У пропонованій статті зроблено спробу розвинути цю синтетичну лінію або, як прийнято говорити, здійснити міждисциплінарний підхід. Орієнтація - на тих 
вчених, які були успішними у поєднанні аналізу мікро- i макрорівнів, взаємозалежності між об'єктивними соціальними структурами різного масштабу і явищами індивідуального і групового менталітету $[25,26]$. Останній, якщо в якості групи виступає народ, нація, часом позначається як «національний характер».

Попри те, що про феномен національного характеру написано представниками різних соціогуманітарних наук чимало (історіографічний огляд виходить за рамки даної статті), відповідної концепції у загально прийнятому вигляді не сформульовано. У дослідженнях виокремлюються наступні підходи. Етнографічний підхід, найбільш традиційний за своїм характером, насамперед спрямований на спостереження i опис побуту i норовів різних народів. Психологічний підхід висуває за мету проникнення «вглиб» особистості за допомогою різних тестів, інтерпретації сновидінь, символів тощо. Історикокультурний підхід відштовхується від аналізу культурного символізму, творів народної творчості та історичних даних [27]. Чимало сучасних науковців вбачають у недоформалізованості терміну певну вигоду, що дозволяє використовувати його у широкому діапазоні i поєднувати різні підходи На це вказує, зокрема, Т.Стефаненко. Разом із тим вона вважає, що «серед підходів до інтерпретації національного характеру провідним слід вважати соціально-історичний, що відстоює принцип соціального або культурного детермінізму» [28]. Схожу думку висловлював І.Кон: «...психоаналітичний підхід до проблеми національного характеру, хоча і зберігає досі деяку автономію, по суті справи став лише етапом переходу від примітивних біологічних теорій до теорій соціально-історичних, у світлі яких спільність психічних рис тієї чи іншої етнічної групи є результатом

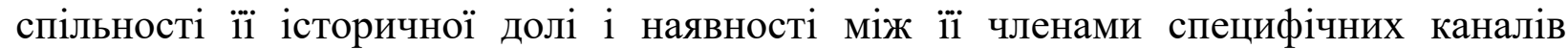
комунікації» [27]. Вчений також наголосив, що ті риси, які нами сприймаються як специфічні особливості національного характеру, $\epsilon$ продуктом специфічних історичних умов і культурних впливів. Вони похідні від історії і змінюються разом iз нею. А потім, із певним відставанням, змінюються і відповідні стереотипи. Істориків найбільше цікавить, в якій мірі можна посилатися на риси національного характеру як на пояснення тих чи інших особливостей історичного розвитку народів і країн.

Попри велику кількість варіантів визначення поняття «національний характер» необхідно мати на увазі хоча б одну. Підручник з політичної психології дає таке формулювання: «Національний характер - сукупність найбільш стійких для даної національної спільноти особливостей емоційно-чуттєвого сприйняття оточуючого світу і форм реакції на нього. Виявляючись в емоціях, почуттях, настроях, національний характер проявляється в національному темпераменті, багато в чому зумовлюючи способи емоційно-чуттєвого освоєння політичної реальності, швидкість та інтенсивність реакції політичних суб'єктів на політичні події, що відбуваються, форми і методи презентації ними своїх політичних інтересів, способи боротьби за їх реалізацію» [29].

Національний характер $є$ продуктом тривалої еволюції суспільства. Він впливає на всі поточні процеси і визначає наперед їх характер, динаміку і напрям у майбутньому. К.Джаррет у своїй статті «Демократія в країні залежить від національного характеру?» стверджує: «Розмови про національний характер насправді не такі безплідні, як може здатися на перший погляд. Загальні риси, притаманні нації, можуть впливати на іiї добробут, задоволеність життям, рівень корупції, здатність до інновацій і навіть на здоров'я... Національний характер 
може впливати навіть на політичну систему в країні» [30]. Мета даної статті продемонструвати вплив особливостей американського національного характеру на перебіг президентської кампанії 2016 року. Характер зумовлює поведінку як висхідний і вирішальний психологічний чинник. На разі цікаво простежити, як спрацював національний характер в конкретній ситуації людського існування, а саме, у виборі лідера провідної держави світу.

Короткий історіографічний начерк стосовно американського характеру ми знаходимо у всесвітньо відомій праці М.Лернера «Розвиток цивілізації в Америці. Спосіб життя і думок у Сполучених Штатах сьогодні» [31, с. 87-88]. Там він називає прізвища таких авторів, як Хейкер, Дейвіс, Бердемейєр, Леві, Ласкі, Уільям, Мірдал, Коммейджер, Невіс, Хедлін, Коулмен, Кревкер, Токвіль. Наводяться показові характеристики. Зокрема із праці «Американське суспільство» Р.М.Уільяма: упор на досягнення мети і успіх, повага до праці і організаторської діяльності, схильність оцінювати життя за моральною шкалою, гуманність, орієнтація на ефективність і практичність, віра у прогрес, любов до матеріального комфорту, проголошення i (хоча би до будь-якої міри) реалізація принципів рівності, прагнення до свободи, готовність до згоди із партнерами, віра в науку і світський раціоналістичний розум, розвинений патріотизм, вірність демократії, культ кожної конкретної особистості, визнання іï самоцінності і гідності, переконаність у расовій і груповій перевазі» [31, с. 87]. Водночас з посиланнями на Л.Коулмена підкреслюється складність i суперечливість американського національного характеру: кожній його рисі можна знайти ії пряму протилежність: «Так американці, безумовно, великодушні, але при цьому дріб'язково скупі, вони щирі і байдужі, романтичні і цинічні, їх можна назвати мрійниками, але складно заплющити очі на їхній прагматизм і ощадливість» [31, с. 88]. Обидва автори підкреслюють ту обставину, що національний характер із часом змінюється. Але деякі риси приписуються американцям у всі епохи. Серед них: віра у демократію, рівність і особисту свободу, повага до «прямої дії», практичність, прагнення до матеріального добробуту, помітна релігійність ортодоксального типу [31, с. 88].

М.Лернер дає своє розуміння поняття «національний характер»: «це категорія, пов’язана не з кров'ю, а культурою. Вона складається із певного спектру цінностей, звичаїв, громадської думки і характерних рис, які поділяються більшістю носіїв даної культури» [31, с. 89]. Також він слушно зауважив: «Ясна річ, у будь-якому суспільстві можна вказати на його типових і нетипових представників і на групу маргінальних суб'єктів, котрих не можна повністю віднести ані до тих, ані до інших, всюди спостерігаються регіональні, класові й етнічні особливості, i, врешті решт, завжди людство дивує нас неосяжною різноманітністю індивідуальних характерів і особистих якостей. 3 іншого боку, американське суспільство зберігає у собі центральний потік, основну тенденцію, а разом із нею плідний, формоутворюючий взаємозв'язок між особистістю американця і американською культурою» [31, с. 91].

Варто враховувати те, що у кризових ситуаціях, у періоди загострення національних проблем і суперечностей ті чи інші риси національного характеру можуть виходити на передній план, детермінуючи політичну поведінку людей [29]. Попри усю велич, набуту Сполученими Штатами Америки за всю історію свого існування, на 2016 рік країна не уникла кризових явищ. Це не тільки вплинуло на політичну поведінку іiї громадян, але й було використано у президентській кампанії Д.Трампа. Взагалі, слід наголосити, що його політтехнологи добре усвідомлювали 
значення психологічної складової в реальному історичному процесі. Вочевидь, в команді Г.Клінтон цього недооцінили. Окремо слід підкреслити, що національний характер проявляється у діяльності окремих особистостей, виявляючи психологічний тип суспільства. I в цьому відношенні Д.Трамп мав переваги перед своїми конкурентами.

Хто підтримав Д.Трампа? Політичні оглядачі сходяться у загальній оцінці, чітко сформульованій О.Ланецьким: «За Трампа голосував традиційний американець - житель одноповерхової Америки, середній клас, робочі, а також натуралізовані емігранти - по ним найбільше б’є приплив нелегалів, і саме їм необхідно довести всім навколо - i в першу чергу, собі самим - свою «американськість» і патріотизм. Трампа підтримали середній i малий бізнес, євангелісти (тобто релігійна більшість) і «чайна партія» - консервативне крило республіканців, яке виросло 3 руху активістів на місцях, слабко пов'язане 3 партійним істеблішментом. За Трампа проголосувала мовчазна більшість Америки, яка хоче жити краще» [6]. О.Білоколос додає: «Феномен Трампа полягав у тому, що він зміг добре відчути настрої чималої кількості білих американців, які належать до робітничого класу, працюють у реальному секторі економіки, не люблять іммігрантів, виступають за збереження християнської спадщини Америки, не довіряють вашингтонському істеблішменту і бояться ісламу. Трамп скористався невдоволенням частини білих американців, фактично очоливши прихований «бунт білих чоловіків» проти популярного гендерного мейнстріму 2000-х. Багато прибічників Трампа значною мірою невдоволені так званою «політкоректністю», серйозно стурбовані політикою демократів, спрямованою на посилення системи контролю за продажем вогнепальної зброї у Сполучених Штатах, і не сприймають того, що сьогодні називають відчуженням влади від народу». I ще: «...очевидно, що проблема значно ширша. Як зазначив напередодні виборів один консервативний оглядач: «Американці більше не впевнені у своєму національному проекті. Вони більше не довіряють інституціям і не мають віри у спільну долю. Це криза національної мети. В основі кризи - сумніви у власній ідентичності та базовому здоров $і ̈$ життя громади» [32].

Д.Трамп і його команда відчули кризу і в країні, і в національному характері. Тому гасло «Make America Great Again» (буквально: «Зробимо Америку знов величною») було сприйнято краще, ніж девіз Г.Клінтон «Stronger Together» («Сильніші разом»). Тут треба підкреслити патріотизм як одну 3 провідних рис американського національного характеру, а також гонористість, яку описував ще А.де Токвіль в Америці 1830-х років [33]. Стосовно гонористості 45-го президента США і того, що він втілює одну з провідних рис національного характеру сучасних американців Дж.А.Бартка пише: «Наступного разу, коли Дональд Трамп сяде за Твіттер, аби похвалитися своєю популярністю або багатством, згадайте, що Токвіль зустрів в Америці таку ж поведінку, коли причалив до іï берегу у 1831 році. Гріхи марнославства і пожадливості були не долею ексцентричної меншості, а радше нормативною характеристикою американської культури. Сьогодні, на відміну від 1831-го пересічні американці, схожі на нас з вами, шукають схвалення товаришів у соціальних мережах і непокояться, чи достатньо вони заробляють, аби жити не гірше сусідів. Легко гудити ці вади у своєму головнокомандувачеві, набагато складніше усвідомити, що ми можемо бути набагато більше схожі на Дональда Трампа, ніж воліли б визнати» [12]. Автор цих слів, і не він один [14, 17, 19, 20, 21 , $22,23]$, дуже критично ставиться і до американського національного характеру, і до 
його типового представника, яким $є$ новий президент. Але у наведеній цитаті можна знайти ще кілька моментів, які сприяють висвітленню обраної теми. А саме: те, що Америка - лідер науково-технічного прогресу, в ній завжди 3 великою повагою ставилися до розвитку науки, причому, новації швидко поширювалися на рівні побутової культури. 3 іншого, серед характерних рис американців індивідуалізм, націленість на досягнення, захоплення успіхом. Тому когось дратують досягнення Д.Трампа, його хвалькуватість викладає презирство, а хтось ним захоплюється. Тим більше, історія бізнесу Д.Трампа знає не тільки перемоги, але й поразки, з яких він виходив, часом із значними здобутками.

В Америці дуже популярним є слово «challenge», тобто «виклик». Його можна розуміти по-різному. Це - не тільки виклик долі, але й обставинам, іншим людям. Так діяли перші переселенці, які перетнули океан і взялися за освоєння нових земель. Так само і Д.Трамп «ніколи не забував урок свого батька: світ - небезпечне місце. Ти маєш бути готовим битися». Про «характер воїна», «завзятого борця за перемогу» написав професор психології Д.П.Макадамс в своїй студії «Розум Дональда Трампа». I зазначив: «Персона Трампа як воїна може надихати деяких американців думати, що він дійсно зможе зробити Америку знову величною, чого б це не коштувало» [15]. Під час президентських виборів 2016 року було зроблено все, аби показати, що настав час рішучих дій, а нерішучість президента-демократа («тільки розмови і ніяких дій») всім набридла. До того ж Д.Трамп являв собою втілення улюбленого американцями оптимізму і динамізму на відміну від дещо нудної i статичної Г.Клінтон. Республіканський кандидат апелював до американського національного характеру. Під час передвиборчої поїздки країною у Геттісберзі він виклав свій контракт із американським виборцем і закликав: «Я прошу американський народ постати над політичною галасливістю і повернутися до віри і оптимізму, на які завжди спирався американський характер, а в цьому світі немає нічого кращого і сильнішого американського характеру» [34].

Слова «зробити Америку величною ЗНОВУ» і є свідченням усвідомлення, що ця величність на теперішній момент втрачена. Пересічного американця, на відміну від пересічного росіянина, в наш час цікавить не стільки зовнішньополітичні акції держави, скільки ситуація в середині країни. Частково це пояснюється тим, що впродовж десятиріч рівень життя в США зростав, і люди звикли до високих життєвих стандартів. Однак останнім часом ситуація погіршилася. М.Кнігге пише: «У багатьох опитуваннях чимало американців не раз заявляли, що їхні стандарти життя та перспективи на майбутнє погіршилися порівняно 3 тими, що мали їхні батьки» [3].

Як зазначає Дж.Ф.Бартка, «згідно дослідженню 2016 р., 69\% американців мають менше 1000 доларів на банківських рахунках, а 34\% взагалі не мають ніяких заощаджень. Маючи стагнацію економічного зростання середнього класу впродовж останніх 30 років, нема чого дивуватися, що так багато американців розцінили голос за Дональда Трампа хорошою ставкою» [12]. Звичайно, зрушення у симпатіях визначає економіка. А Д.Трамп пообіцяв вирішити проблему стагнації, масової реіндустріалізації і скасування тих приписів, які вбивають робочі місця 3 тим, аби вугільна, нафтовидобувна і виробнича промисловість прийняла назад на роботу величезну кількість людей. Деякі економісти доводять, що всі ці обіцянки «нісенітниця», даються пояснення причин негараздів [17]. Лунало дуже багато звинувачень на адресу кандидата від республіканців у популізмі. Але хіба саме 
слово не походить від латинського «народ»? I хіба американський народ не цінує матеріальний комфорт?

У своїй книзі «Країна фантазій: як Америка з’їхала 3 глузду» К.Андерсен стверджує, що президентство Д.Трампа є логічною кульмінацією тривалої історії американської суперрелігійності, байдужості до фактів, які можна перевірити, i екстатичного прийняття надприродного, фантастики та необізнаних тверджень: «Дональд Трамп - логічний результат американського зачарування ірраціональним» [35]. Дослідник також зазначає: «Америка зруйнувала пробіл між розвагою і новинами, реальністю і нереальністю, серйозним і несерйозним. Це божевільний коктейль - частина американського життя, частина нашої культури і системи цінностей. Людям байдуже, що реальність, а що вигадка. Вони лише хочуть, щоби їх розважали» [35].

У своїй праці «Американський характер», вперше виданій у 1944 р. професор Д.У.Броган показував, як «американський досвід» породив серед інших настанов «темперамент гравця» в американських поселенцях. Х.Харе помітив: «... на президентських виборах 2016 р. американці в більшості піддалися темпераменту гравців, проголосувавши за людину, яка суперечила кожному із відомих параметрів надійності, компетентності і доброчесності. Решта світу могла вважати цю ставку несмаком, проте Дональд Трамп розробив кампанію, яка потурала внутрішнім страхам i занепокоєнням американців. Простіше кажучи, Трамп ближче до американського характеру, ніж його супротивники» [21]. До речі, в англійській мові «trump» може перекладатися і як «козир», і як «славний хлопець».

Сам Д.Трамп прагнув бути ближче до своїх співгромадян. Він зробив чимало в якості своєрідного лайфкоуча - буквально, «тренера життя». Діяв не тільки життєвий приклад успішного бізнесу, яким мільярдер волів ділитися. Для цього видавалися книжки 3 промовистими назвами «Як стати багатим», «Шлях до успіху», «Шлях на вершину. Найкращі поради з бізнесу, які я тільки одержував», «Думай як чемпіон: Неформальне навчання 3 бізнесу i життя», «Думай як мільярдер. Все, що слід знати про успіх, нерухомість і життя взагалі», «Мистецтво укладати угоди», «Дотик Мідаса», «Трамп ніколи не здається: Як я перетворив мій найбільший виклик на успіх» та ін.

Д.Трампа багато хто $з$ оглядачів називає «шоуменом». Зокрема, М.Флемінг пише: «Трамп походить 3 довгого ряду галасливих американських шоуменів із вродженою здатність влучати у національний настрій... Ймовірно, краще, ніж будь-хто Трамп розуміє, що наша культура стала культурою знаменитостей, оскільки він сам же допомагав іiі створити. Слава, подібна його, не може бути відмінусованою, і в практичному сенсі коштує десятків мільйонів доларів, які йому вже не знадобилося витрачати на традиційні пастки передвиборчої кампанії» [20]. В свій час будівельний магнат став одним із найбільш оплачуваних телеведучих. У 2002 р. було запущено у прайм-тайм ріеліті-шоу «Кандидат», учасники якого змагалися між собою за право стати топ-менеджером в його компанії. У 2006 р. мільярдер спільно із NBC викупив компанію Miss Universe Organization, яка займалася організацією конкурсів краси «Міс Всесвіт» $\mathrm{i}$ «Mic Америка» (безпосереднє відношення до створення «зірок», до чого американський національний характер має велику прихильність). Двічі він номінувався на премію Еммі за ролі самого себе в серіалах і фільмах, зокрема у фільмі «Один вдома 2», де він пояснює маленькому хлопчику дорогу в власному готелі. Тобто людина має почуття гумору. Риса, варта симпатій багатьох американців. 
Американські автори ставлять питання: «Мільйони посадили Трампа в Овальний кабінет. Що це говорить про країну?» [14]. Або: «Що перемога Трампа говорить про американський характер?» [21]. Деякі, зокрема Х.Харе, вважають, «квінтесенція американського характеру знов ствердила себе». Разом із тим він вказує, що «кожні президентські вибори підкреслюють старі лінії напруги і являють увазі нові. Кампанія Трампа черпала свою енергію, яка здавалася невичерпною, із сприйняття іiі як руху, спрямованого на повалення існуючого порядку... Перемога Дональда Трампа - це не тільки голосування від протилежного, спрямоване на те, аби тримати подалі від Білого Дому «корумповану Гілларі» i iii настільки ж нелюбого чоловіка; це і позитивне голосування, яке дало вихід нерозведеній люті білих американців і обіцяє переписати вашингтонські правила відповідно американському характеру». Водночас X.Харе вважає що Д.Трамп «виніс на поверхню достатньо нашої темної сторони, аби довести до краю загрозу національній безпеці» [21].

Показовою є та обставина, що превалюють жорсткі оцінки у співвідношенні Дональд Трамп - американський характер. Відомо, що обрання нового президента вітали далеко не всі американці. I до, і після того його піддавали критиці насамперед представники інтелектуальної еліти США (а саме невдоволення американців прірвою між елітою і суспільством і відчув Д.Трамп). 3 іншого боку, наводяться дані, відповідно до яких 32 млн. дорослих у Сполучених Штатах не вміють читати, 44 млн. дорослих неспроможні прочитати своїм дітям просту історію. Дж.Флаттум пише: «...Очевидно, що країною править невігластво. Невже і дійсно Америка така нерозумна?» [19]. Х.Харе висуває риторичне запитання: «Чи дійсно ми - расисти, лицеміри і патологічні брехуни, позбавлені співчуття?» I сам відповідає: «Ні, Трамп і його прихильники не представляють характер усієї Америки, слава Богу. I не всі його прибічники - погані люди. Було б абсурдним так стверджувати. Узагальнення небезпечні» [21].

Хоч «узагальнення небезпечні», проте висновки статті мають бути сформульовані. Насамперед, дослідження національного характеру - складна справа: завжди залишається щось, що не можна осягнути до самого донця. Діалектика виявляється не тільки у цьому. Вона - у поєднанні позитивних і негативних рис національного характеру, а також у його розвиткові. Можна погодитися із І.Коном, який писав: «...суперечливі риси можуть не лише втілюватися у різних людях (чому і ризиковано приймати окрему особистість, навіть найвидатнішу, за втілення національного характеру), але історичні умови, що змінюються, можуть сприяти переважному прояву, а отже, і закріпленню одних рис на шкоду іншим... Національний характер $є$ вельми стійким, його неможна змінити за допомогою адміністративних заходів або просвітництва. Однак, оскільки він є історичним, він змінюється разом із суспільним устроєм» [27].

Перемога на президентських виборах 2016 р. Д.Трампа виявилася для багатьох аналітиків, і не тільки аналітиків, неочікуваною. Як зазначив Е.Зуркер: «Він перевернув 3 ніг на голову загальноприйняту мудрість щодо того, як стати президентом» [2]. Його висміювали, але його рішення спрацювали. На думку приходять загальновідомі пояснення того, як підносяться видатні історичні особи: вони відчувають масові настрої і виявляються спроможними «осідлати хвилю». 45му президенту США це вдалося. Перемога Д.Трампа - це перемога тих, хто його підтримував. Пригадується сентенція про народні маси - творців історії. У даному випадку ми маємо яскраве тому підтвердження. Економічна і політична ситуація 
можуть або посилювати, або послаблювати міру прояву тих чи інших рис національного характеру. У тому, як завершилися президентські вибори 2016 р. в США, виявилися різні особливості американського характеру. Для дослідника взагалі є цікавим спостереження за тим, як на історію впливають ідеї, прагнення, уявлення, переживання людей. Вивчення Сполучених Штатів Америки являє особливий інтерес і значення, бо їхній суперечливий внутрішній розвиток певною мірою визначає стан світового політичного і економічного середовища, що не може не цікавити Україну.

\section{Література}

1. Гоган Е. Чому саме Трамп потрапив до Білого Дому. П'ять причин [Електронний ресурс] - Режим доступу: http://nv.ua/ukr/opinion/gaughan/chomu-same-tramp-potrapiv-v-bilij-dim-p-jatprichin-264949.html- Дата звернення: - 17.10.2017. - Назва з екрану.

2. Зуркер Е. П'ять причин, чому Трамп переміг [Електронний ресурс] - Режим доступу: http://www.bbc.com/ukrainian/politics/2016/11/161109_trump_victory_five_reasons_or_it Дата звернення: - 17.10.2017. - Назва з екрану.

3. Кнігге М. Історична перемога Трампа, безпорадний Захід та багато відкритих питань [Електронний pecypc] - Режим доступу: http://www.dw.com/uk - Дата звернення: - 15.10.2017. Назва з екрану.

4. Реальные причины победы Трампа [Электронный ресурс]. - Режим доступа: http://nk.org.ua/geopolitika/realnyie-prichinyi-pobedyi-trampa-83652 - Дата звернення: - 12.10.2017. Назва з екрану.

5. Чому переміг Трамп: «наукове» пояснення [Електронний ресурс]. - Режим доступу: https://day.kyiv.ua/uk/article/ekonomika/chomu-peremig-tramp-naukove-poyasnennya - Дата звернення: - 10.10.2017. - Назва з екрану.

6. Ланецький О. Як і чому переміг Трамп [Електронний ресурс] - Режим доступу: http://forbes.net.ua/ua/opinions/1423725-yak-i-chomu-peremig-tramp -Дата звернення: - 6.10.2017. Назва з екрану.

7. Карпенко А. Чому Трамп переміг? [Електронний ресурс] - Режим доступу: http://kievvlast.com.ua/mind/chmu_tramp_peremig45520 - Дата звернення: - 6.10.2017. - Назва 3 екрану.

8. Мацієвський Ю. Чому переміг Трамп? [Електронний ресурс] - Режим доступу: https://zaxid.net/chomu_peremig_tramp_n1410937.- Дата звернення: - 9.10.2017. - Назва з екрану.

9. Михайленко М. Пять главных причин победы Дональда Трампа [Электронный ресурс] Режим доступа: http://newssky.com.ua/5-glavnyih-prichin-pobedyi-donalda-trampa/ - дата обращения: 17.10.2017. - Название с экрана.

10. Сердюк Н. Чому Трамп переміг на виборах [Електронний ресурс]- Режим доступу: http://obla.co.ua/news/politics/why-trump-won-the-elections -Дата звернення: - 12.10.2017. - Назва 3 екрану.

11. Перемога Трампа. Прощання зі стереотипами [Електронний ресурс]. - Режим доступу: https://ukr.lb.ua/world/2016/11/10/350359_peremoga_trampa_proshchannya_zi.html - Дата звернення: - 19.10.2017. - Назва з екрану.

12. Burtka J.A. Face It: Trump Is the Man in America's Mirror. The American Conservative. [Electronic Resource] - Mode of Access: http://www.theamericanconservative.com/articles/face-ittrump-is-the-man-in-americas-mirror (Last Access: $12^{\text {th }}$ October 2017) - Title from the Screen.

13. Gonzales R. Trump embodies the dark side of American Exceptionalism [Electronic Resource] - Mode of Access: http://www.bakersfield.com/opinion/trump-embodies-the-dark-side-of-americanexceptionalism/article_d72e1f87-09dd-5ad4-a415-e0456937d9be.html (Last Access: $10^{\text {th }}$ October 2017) Title from the Screen.

14. King C.I. Americans put Trump in the Oval Office. What does that say about the country? [Electronic Resource] - Mode of Access: https://www.washingtonpost.com/opinions/americans-puttrump-in-the-oval-office-what-does-that-say-about-americans/2017/07/14/e6dd8996-67e8-11e7-a1d79a32c91c6f40_story.html (Last Access: 12 ${ }^{\text {th }}$ October 2017) - Title from the Screen.

15. Mcadams D.P. The Mind of Donald Trump. [Electronic Resource] - Mode of Access: https://www.theatlantic.com/magazine/archive/2016/06/the-mind-of-donald-trump/480771/ (Last Access: $11^{\text {th }}$ October 2017) - Title from the Screen. 
16. Mardell M. Tump and Obama: Two characters in search of a legacy [Electronic Resource] Mode of Access: http://www.bbc.com/news/world-us-canada-38663825 (Last Access: 25 ${ }^{\text {th }}$ October 2017) - Title from the Screen.

17. Meeropol M. Decline Of American Character Not To Blame. WAMC Northeast Report. [Electronic Resource] - Mode of Access: http://wamc.org/post/michael-meeropol-decline-americancharacter-not-blame (Last Access: $27^{\text {th }}$ October 2017) - Title from the Screen.

18. Shaffer J. Pulitzer-winning historian on Trump: "Character is destiny...No one should be surprised". [Electronic Resource] - Mode of Access: http://newsobserver.com/news/politicsgoverment/article151016877.html (Last Access: 12 ${ }^{\text {th }}$ October 2017) - Title from the Screen.

19. Flattum J. Trump Defiles American National Character [Electronic Resource] - Mode of Access: https://www.linkedin.com/pulse/trump-defiles-americas-national-character-jerry-flattum (Last Access: $14^{\text {th }}$ October 2017) - Title from the Screen.

20. Fleming M. Donald Trump: An over-the-top American character [Electronic Resource] - Mode of Access: http://delawareonline.com/story/opinion/contributors/2015/08/24/donald-trump-top-americancharacter/ 32280723 (Last Access: $12^{\text {th }}$ October 2017) - Title from the Screen.

21. Khare H. What Trump's Victory Says About The American Character [Electronic Resource] Mode of Access: http://www.huffingtonpost.in/harish-khare-/what-trump-s-victory-says-about-theamerican-character_a_21605212. (Last Access: $12^{\text {th }}$ October 2017) - Title from the Screen.

22. Henderson S. American character can survive Trump. Detroit Free Press. [Electronic Resource]

Mode of Access: http://www.freep.com/story/opinion/columnists/stephenhenderson/2017/07/02/trump-american-values/442086001 (Last Access: 12 ${ }^{\text {th }}$ October 2017) - Title from the Screen.

23. Huer J. Donald Trump: Made in the USA. Lanham - Boulder - New-York - Toronto Plymouth UK: Hamilton Books. - 206 p.

24. Готовкіна Л.Д. Національний характер: проблема дефініції поняття /Л. Готовкіна //Наукові записки. Серія «Психологія і педагогіка». - Острог: Видавництво Національного університету «Острозька академія». - 2008. - Вип. 11. - С. 45-55.

25. Бурдьё П. Практический смысл /П.Бурдьё. - СПб.: Алетейя, М.: «Институт экспериментальной социологии», 2001 г. - 562 c.

26. Collins R. Macrohistory: Essays in Sociology of the Long Run. Stanford: Stanford University Press. $-328 \mathrm{p}$.

27. Кон И. К проблеме национального характера [Электронный ресурс]. - Режим доступа: https://scepsis.net/library/id_903.html (дата обращения: 2 октября 2017 г.). - Название с экрана.

28. Стефаненко Т.Г. Этнопсихология. 2.2.Национальный характер или ментальность? /Татьяна Гавриловна Стефаненко. - 3-е изд., испр. и доп. - М.: Аспект Пресс, 2004 - 368 с. [Электронный ресурс]. - Режим доступа: https://psy.wikireading.ru/12716. (дата обращения: 2 октября 2017 г.). - Название с экрана.

29. Политическая психология. Учебное пособие для высшей школы. - М.: Деловая книга, 2001 [Электронный pecypc]. https://studme.org/55923/psihologiya/ponyatie_natsionalnogo_haraktera (дата обращения: 2 октября 2017 г.). - Название с экрана.

30. Джаррет К. Демократия в стране зависит от национального характера? [Электронный pecypc]. - Режим доступа: http://www/bbc.com/russian/vert-fut-40962685(дата обращения: 2 октября 2017 г.). - Название с экрана.

31. Лернер М. Развитие цивилизации в Америке. Образ жизни и мыслей в Соединенных Штатах сегодня /Пер. с англ. - В 2 тт.- М.: Радуга, 1992. Т.1. - 671 с.; Т.2. -575 с.

32. Білоколос О. Вибори президента США: як сталося неймовірне, і чого очікувати Україні? [Електронний ресурс]. - Режим доступу:https://dt.ua/internal/vibori-prezidenta-ssha-yak-stalosyaneymovirne-i-chogo-ochikuvati-ukrayini-_.html (дата звернення: 2 жовтня 2017 p.) - Назва з екрану.

33. Токвіль, А. де. Про демократію в Америці /Алексіс де Токвіль / Пер. 3 фр. Г. Філіпчук, М. Москаленко. - К.: Всесвіт, 1999. - 590 с.

34. Речь Дональда Трампа в Геттисберге, штат Пенсильвания (22 октября 2016 года) [Электронный ресурс]. - Режим доступа: http://inosmi.ru/politic/20161023/238066206.html (дата обращения: 2 октября 2017 г.). - Название с экрана.

35. Andersen K. Americans have a longstanding love of magical thinking. It gave us Trump. [Electronic Resource] - Mode of Access: https://www.vox.com/2017/9/29/16349982/americans-lovemagical-thinking-it-gave-us-trump (Last Access: $24^{\text {th }}$ October 2017) - Title from the Screen. 


\section{References}

1. HOHAN, E. (2016) Chomu same Tramp potrapyv do Biloho Domu. Pyat prychyn [Online]. Available from: http://nv.ua/ukr/opinion/gaughan/chomu-same-tramp-potrapiv-v-bilij-dim-p-jat-prichin264949.html [Accessed: 17th October 2017]

2. ZURKER, E. (2016) Pyat prychyn, chomu Tramp peremih [Online]. Available from: http://www.bbc.com/ukrainian/politics/2016/11/161109_trump_victory_five_reasons_or_it [Accessed: 17th October 2017]

3. KNIHHE, M. (2017) Istorychna peremoha Trampa, bezporadnyj Zaxid ta bahato vidkrytyx pytan [Online]. Available from: http://www.dw.com/uk [Accessed: 15th October 2017]

4. Realnye prychyny pobedy Trampa (2016) [Online]. Available from: http://nk.org.ua/geopolitika/realnyie-prichinyi-pobedyi-trampa-83652 [Accessed: 12th October 2017]

5. Сhоти peremih Tramp: naukove poyasnennya (2016) [Online]. Available from: https://day.kyiv.ua/uk/article/ekonomika/chomu-peremig-tramp-naukove-poyasnennya [Accessed: 10th October 2017]

6. LANECKYJ, O. Yak i chomu peremih Tramp (2016) [Online]. Available from: http://forbes.net.ua/ua/opinions/1423725-yak-i-chomu-peremig-tramp [Accessed: 6th October 2017]

7. KARPENKO, A. (2016) Chomu Tramp peremih? [Online]. Available from: http://kievvlast.com.ua/mind/chmu_tramp_peremig45520 [Accessed: 6th October 2017]

8. MACIYEVSKYJ, Yu. Chomu peremih Tramp? (2016) [Online]. Available from: https://zaxid.net/chomu_peremig_tramp_nl410937 [Accessed: 9th October 2017]

9. MYXAJLENKO, M. (2016) Pyat hlavnyx prychyn pobedy Donalda Trampa [Online]. Available from: http://newssky.com.ua/5-glavnyih-prichin-pobedyi-donalda-trampa/ [Accessed: 17th October 2017]

10. SERDYUK, N. Chomu Tramp peremih na vyborax (2016) [Online]. Available from: http://obla.co.ua/news/politics/why-trump-won-the-elections [Accessed: 12th October 2017]

11. Peremoha Trampa. Proshhannya zi stereotypamy (2016) [Online]. Available from:

https://ukr.lb.ua/world/2016/11/10/350359_peremoga_trampa_proshchannya_zi.html [Accessed: 19th October 2017]

12. BURTKA, J.A. (2017) Face It: Trump Is the Man in America's Mirror. The American Conservative. [Online] 12th August. Available from: $\mathrm{http}: / / \mathrm{www}$.theamericanconservative.com/articles/face-it-trump-is-the-man-in-americas-mirror [Accessed: 12th October 2017]

13. GONZALES, R. (2016) Trump embodies the dark side of American Exceptionalism [Online]. Available from: http://www.bakersfield.com/opinion/trump-embodies-the-dark-side-of-americanexceptionalism/article_d72e1f87-09dd-5ad4-a415-e0456937d9be.html [Accessed: 10th October 2017]

14. KING, C.I. (2017) Americans put Trump in the Oval Office. What does that say about the country? The Washington Post. [Online] 14th July. Available from: https://www.washingtonpost.com/opinions/americans-put-trump-in-the-oval-office-what-does-that-sayabout-americans/2017/07/14/e6dd8996-67e8-11e7-a1d7-9a32c91c6f40_story.html [Accessed: 12th October 2017]

15. MCADAMS, D.P. (2016) The Mind of Donald Trump. The Atlantic's Politics\&Policy Daily. [Online] June. Available from: https://www.theatlantic.com/magazine/archive/2016/06/the-mind-ofdonald-trump/480771/ [Accessed: 11th October 2017]

16. MARDELL, M. (2017) Tump and Obama: Two characters in search of a legacy [Online] Available from: http://www.bbc.com/news/world-us-canada-38663825 [Accessed: 25th October 2017]

17. MEEROPOL, M. (2017) Decline Of American Character Not To Blame. WAMC Northeast Report. [Online] 3d March. Available from: http://wamc.org/post/michael-meeropol-decline-americancharacter-not-blame. [Accessed: 27th October 2017]

18. SHAFFER, J. (2017) Pulitzer-winning historian on Trump: "Character is destiny...No one should be surprised". [Online] Available from:http://newsobserver.com/news/politicsgoverment/article151016877.html [Accessed: 12th October 2017]

19. FLATTUM, J. (2016) Trump Defiles American National Character [Online] Available from: https://www.linkedin.com/pulse/trump-defiles-americas-national-character-jerry-flattum [Accessed: 14th October 2017]

20. FLEMING, M. (2016) Donald Trump: An over-the-top American character [Online]. Available from: http://delawareonline.com/story/opinion/contributors/2015/08/24/donald-trump-top-americancharacter/32280723 [Accessed: 14th October 2017] 
21. KHARE, H. (2017) What Trump's Victory Says About The American Character [Online] Available from: http://www.huffingtonpost.in/harish-khare-/what-trump-s-victory-says-about-theamerican-character_a_21605212. [Accessed: 12th October 2017]

22. HENDERSON, S. (2017) American character can survive Trump. Detroit Free Press. [Online] 1st July 2017. Available from: http://www.freep.com/story/opinion/columnists/stephenhenderson/2017/07/02/trump-american-values/442086001 [Accessed: 12th October 2017]

23. HUER, J. (2017) Donald Tramp: Made in the USA. Lanham - Boulder - New-York - Toronto - Plymouth UK: Hamilton Books.

24. HOTOVKINA, L.D. (2008) Nacionalnyj xarakter: problema definiciyi ponyattya. Naukovi zapysky. Seriya Psyxolohiya i pedahohika. - Ostroh: Vydavnyctvo Nacionalnoho universytetu Ostrozka akademiya. 11, P. 45-55.

25. BURDE, N. (2001) Praktycheskyj smysl. S-Peterburg, Moskva: Ynstytut eksperymentalnoj socyolohyy.

26. COLLINS, R. (1999) Macrohistory: Essays in Sociology of the Long Run. Stanford: Stanford University Press.

27. KON, Y. K probleme nacyonalnoho xaraktera (1971) [Online] Available from: https://scepsis.net/library/id_903.html [Accessed: 2d October 2017]

28. STEFANENKO, T. (2004) Etnopsyxolohyya. Moskva: Aspekt Press. [Online] Available from: https://psy.wilcireading.ru/12716 [Accessed: 2d October 2017]

29. Polytycheskaya psyxolohyya. Uchebnoe posobye dlya vysshej shkoly (2001). Moskva: Delovaya knyha. [Online] Available from: http://studme.org/55923/psihologiya/ponyatie_natsionalnogo_haraktera [Accessed: 3d October 2017]

30. DZHARRET, K. (2017) Demokratyya v strane zavysyt ot nacyonalnoho xaraktera? [Online] Available from: http://www.bbc.com/russian/vert-fut-40962685 [Accessed: 6th October 2017]

31. LERNER, M. (1992) Razvytye cyvylyzacyy v Ameryke. Obraz zhyzny y myslej v Soedynennyx Shtatax sehodnya. Moskva: Raduha.

32. BILOKOLOS, O. (2016) Vybory prezydenta SShA: yak stalosya nejmovirne, i choho ochikuvaty Ukrayini? [Online] Available from: https://dt.ua/internal/vibori-prezidenta-ssha-yak-stalosyaneymovime-i-chogo-ochikuvati-ukrayini-_.html [Accessed: 19th October 2017]

33. TOKVIL, A. de. (1999) Pro demokratiyu v Ameryci. Kyiv.: Vsesvit.

34. Rech Donalda Trampa v Hettysberhe, shtat Pensylvanyya (22 oktyabrya 2016 hoda) (2016) [Online] Available from: http://inosmi.ru/politic/20161023/23 8066206.html [Accessed: 1st October 2017]

35. ANDERSEN, K. (2017) Americans have a longstanding love of magical thinking. It gave us Trump. Vox. [Online] Available from: https://www.vox.com/2017/9/29/16349982/americans-lovemagical-thinking-it-gave-us-trump [Accessed: 24th October 2017]

Надійшла до редколегії 01.09.2017

Tetiana Orlova, Dr. habil. (history), Professor National Taras Shevchenko University of Kyiv

\section{THE FACTOR OF AMERICAN NATIONAL CHARACTER IN THE VICTORY OF DONALD TRUMP}

Abstract. In the current Ukrainian historical science, the perception of requiring new conceptual approaches for explaining past and current processes and events is growing fast. An important part belongs to interdisciplinarity that considerably increases the opportunities of research in shaping and explaining topical issues, including the factors of influence by the USA and on the USA. The article researches the influences of American national character on the run of 2016 American presidential campaign, combining analyses at the micro- and macro-levels, i.e. electoral and individual. Donald Trump has demonstrated his proximity to the majority of voters, appealing to the American nature. At the same time, the national temper has been manifested in his activities. As history witnesses, under conditions of deep crisis some features of a national temper may come to the forefront, determining people's political behavior. Today's USA wouldn't evade the crisis phenomena both in terms of economy and identity. Donald Trump and his team have sensed it well and used it in their pre-electoral work, whereas their 
adversaries have underestimated the weight of the psychological component in the real historical process. The comments of American analytics on the subject demonstrate the discrepancy between the views of the "elite" and the "masses". The victory in the elections to the highest position in a leading nation of the world serves as another example of the importance of the broad public as the makers of history, as well as of the factors that ensure success to extraordinary personalities, to which Donald Trump most certainly belongs.

Key words: the USA, presidential elections, national character, Donald Trump.

УДК 359.09

Ігор Смирнов, доктор географічних наук, професор, Київський національний університет імені Тараса Шевченка

\title{
РЕСУРСНА БАЗА ВІЙСЬКОВОГО ТУРИЗМУ США ТА ÏÏ РЕГІОНАЛЬНІ ОСОБЛИВОСТІ \\ (НА ПРИКЛАДІ ПАМ'ЯТОК ВІЙНИ ЗА НЕЗАЛЕЖНІСТЬ ТА ГРОМАДЯНСЬКОЇ ВІЙНИ)
}

\begin{abstract}
Анотація. Розкрито особливості ресурсної бази військового туризму на прикладі США, які включають, зокрема, військово-історичні туристичні об'єкти, пов'язані з американською Війною за незалежність та Громадянською війною. Показано поділ військового туризму на такі його підвиди, як військово-історичний, мілітарі, військовоісторичні фестивалі та реконструкиії. Наведено перелік краӥн світу - лідерів щзоо кількості туристичних прибуттів та обсягу доходів від туризму, а також місие США у цьвому реєстрі. Виявлено особливості воєнно-історичних туристичних об'єктів США, пов'язаних з Війною за незалежність (1775-1783 рр.) та з Громадянською війною у Сполучених Штатах (1861-1865 рр.). Проаналізовано географічні особливості ресурсної бази американського військового туризму XVIII та XIX cm. Результати аналізу наведено у таблиці, з якої видно, щуо об'єкти ресурсної бази туризму, пов'язані з Війною за незалежність, зосереджені у чотирьох итатах США (Вірджинія, Нью-Йорк, Федеральний округ Колумбія та Північна Кароліна), а туристичні об'єкти, пов'язані з Громадянською війною, розташовані у восьми штатах (Пенсільванія, Федеральний округ Колумбія, Південна Кароліна, Теннесі, Меріленд та Міссісіпі).
\end{abstract}

Ключові слова: військовий туризм, ресурсна база, США, Війна за незалежність, Громадянська війна.

Постановка наукової проблеми. США - держава, яка займає перше місце у світі за туристичними доходами та друге - за туристичними потоками. У цій країні розвинуті усі види туризму, але особливу увагу американці приділяють військовопатріотичному туризму, який орієнтований передусім на власну молодь, але не тільки. Військова історія США, як і уся історія цієї держави, - не така довга, як, для прикладу, України, і налічує трохи більше двох сторіч. Дана стаття орієнтована на розкриття регіональних особливостей ресурсної бази військового туризму США XVIII-XIX ст., коли головними подіями їхньої військової історії були Війна за незалежність (1775-1783 рр.) та Громадянська війна (1861-1865рр.).

Аналіз останніх досліджень і публікацій. Тема статті в аспекті, що розглядається, практично не знайшла відображення в історичній та туристичній літературі. При цьому сучасні різновиди туризму, у т.ч. військовий, розкрито у 